\title{
The Role of the DAPIA in the Manufactured Housing Process
}

S. Balistocky

A. D. Lee

S. A. Onisko

March 1986

Prepared for the Bonneville Power Administration under a Related Services Agreement with the U.S. Department of Energy Contract DE-AC06-76RLO 1830

Pacific Northwest Laboratory Operated for the U.S. Department of Energy by Battelle Memorial Institute 


\title{
DISCLAIMER
}

This report was prepared as an account of work sponsored by an agency of the United States Government. Neither the United States Government nor any agency thereof, nor any of their employees, makes any warranty, express or implied, or assumes any legal liability or responsibility for the accuracy, completeness, or usefulness of any information, apparatus, product, or process disclosed, or represents that its use would not infringe privately owned rights. Reference herein to any specific commercial product, process, or service by trade name, trademark, manufacturer, or otherwise, does not necessarily constitute or imply its endorsement, recommendation, or favoring by the United States Government or any agency thereof. The views and opinions of authors expressed herein do not necessarily state or reflect those of the United States Government or any agency thereof.

\author{
PACIFIC NORTHWEST LABORATORY \\ operated by \\ BATTELLE \\ for the \\ UNITED STATES DEPARTMENT OF ENERGY \\ under Contract DE-AC06-76RLO 1830
}

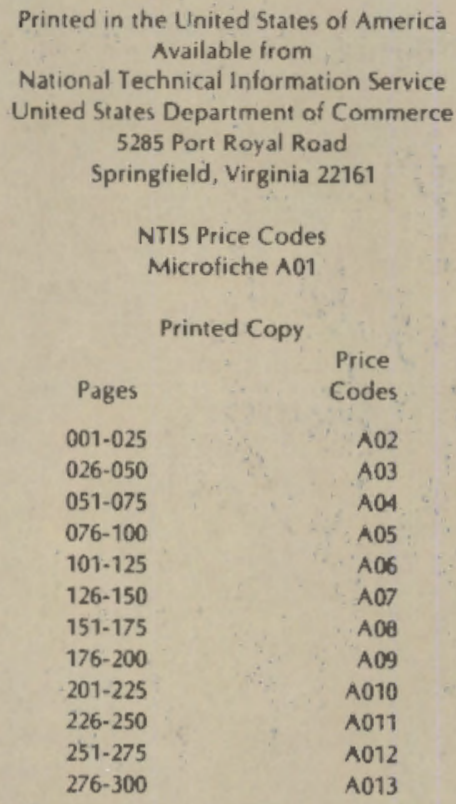


THE ROLE OF THE DAPIA IN THE MANUPACTURED HOUSING PROCESS

S. Balistocky

A. D. Lee

S. A. Onisko(a)

February 1986

Prepared for the office of Conservation Bonneville Power Administration under a Related Services Agreement with the U.S. Department of Energy Contract DE-ACO6-76RLO 1830

Pacific Northwest Laboratory

Richland, Washington 99352

(a) Bonneville Power Admintstration, Portland, Oregon 
I 
The Bonneville Power Adninistration (BPA) is pursuing steps to increase the energy efficiency of manufactured (mobile) homes in the Pacific Northwest. Manufactured homes constitute as much as $50 \%$ of new single-family housing starts, yet they fall outside the scope of local code agencies. Manufactured homes follow a different design and marketing process than site-built homes. A better understanding of the participants in this process will help BPA develop successful approaches to achieve manufactured housing energy conservation.

This paper describes the function of Design Approval Primary Inspec$t$ lon Agencies (DAPIAs) and provides some insights into the design approval process for manufactured housing units.

DAPIAs play a key role in assuring that the designs for manufactured housing units are in compliance with HUD's Manufactured Housing Construction and Safety standards. There are five DAPIAs performing plan checks and design reviews for the manufacturers operating in the Pacific Northwest region. The costs to a manufacturer for DAPIA services ranges from $\$ 100$ to $\$ 250$ to approve modifications to existing designs and $\$ 700$ to $\$ 1200$ to approve a totally new design.

Each DAPIA indicated that they would be willing to work with BPA in some way to assist manufacturers produce units which can achieve MCS levels. They would be available for energy design consultation on an informal basis. In addition they would be willing to consider formal certifications of MCS designs if BPA develops evaluation criteria which they can apply. 
.

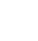


SUMMARY $\ldots \ldots \ldots \ldots \ldots \ldots \ldots \ldots \ldots \ldots \ldots \ldots \ldots \ldots \ldots \ldots \ldots \ldots$

1.0 INTRODUCTION ....................... 1.1

1.1 BACKGROUND . . . . . . . . . . . 1.2

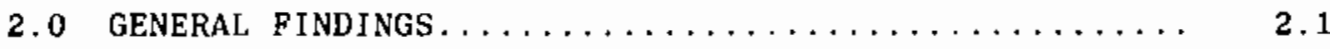

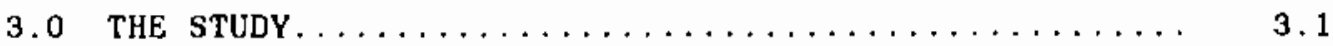

3.1 DAPIAS THAT PROVIDE SERVICES TO THE

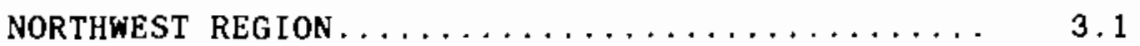

3.1 .1 The Conventence Issue $\ldots \ldots \ldots \ldots \ldots \ldots .4$

3.1 .2 The Quality Issue................ 3.4

3.1 .3 Efficiency Issues............... 3.5

3.1 .4 Cost Issues................... 3.6

3.2 THE PROCESS USED BY MANUFACTURERS TO OBTAIN DAPIA APPROVAL FOR NEW DESIGNS AND DESIGN

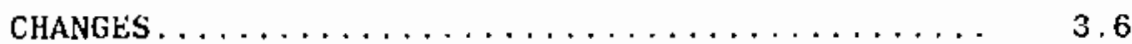

3.3 THE COST OF SERVICES RENDERED BY A DAPIA

AND THE UNIFORMITY OF THESE CHARGES . . . . . . 3.8

3.4 THE AMOUNT OF TIME NEEDED TO CERTIFY A NEW

DESIGN . . . . . . . . . . . . . . . . . . . 3.8

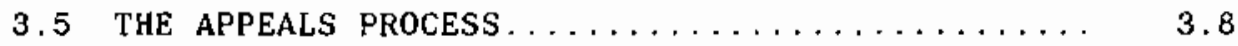

3.6 THE DAPIA ROLE IN THE DESIGN, ANALYSIS AND APPROVAL OF MODEL CONSERVATION STANDARD HOMES ... 3.9

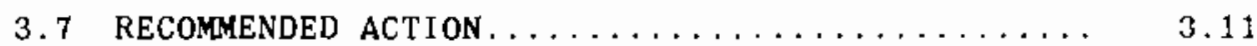





\subsection{INTRODUCTION}

Thlo study addresses the role of Design Approval Prinary Inspection Agencies (DAPIAs) in the approval and manufacturer of manufactured homes in the Pacific Northwest. Understanding the roie of DAPIAs and other participants in the nanufactured housing market is critical in developing successful energy conservation programs that achieve energy efficlency improvements in manufactured hones.

The Code of Federal Regulations, Part 24 Section 3280 et.seq., sets for th all the requirements which must be met by the manufacturers of manufactured homes for sale to purchasers. These regulations were adopted to assure that all new manufactured housing units are designed and constructed to meet the Department of Housing and Urban Development's (HUD) Construction and Safety standards. Included in these regulations are the specific requirements governing the design approval, design certif lcation and unit inspection processes which must be conplied with before any unit can be offered for sale to the public. For these purposes, HuD established a number of agencles and divided these responsibilities accordingly. The agencies created under this authority include the Design Approval Primary Inspection Agencies (DAPIAs), Inspection Primary Inspection Agencies (IPIAs) and State Administrative Agencles (SAAs).

In addition, HUD has created a significant role for the National Conference on Building Codes and Standards (NCSBCS) with whoti it has contracted to monitor the performance of the DAPIAs. This contract, which must be recompeted every three years, requires NCSBCS to annually spot-check DAPIA design approvals for compliance with HUD Standards and issue ratings based on their findings.

The HUD standards are preemptive standards. This means that neither states nor other federal agencies may institute or substitute their own standards to regulate the design, construction, production, inspection, or transportation of manufactured housing. The only area in which a state reta1ns any jurisdiction which might impact manufactured housing is in the area of zoning controls. 


\subsection{BACKGROUND}

A study, Energy-efficient Manufactured Housing perforned by Steve Onisko, office of Conservation, Bonneville Power Administration in March 1985, produced results indicating that manufactured housing represents as much as $60 \%$ of all the new housing starts in the rural parts of the region. BPA's principal service territory. Little is known regarding the conservation levels to which these units are being designed, the extent to which they can be redesigned to achleve destred energy conserving levels safely or without violating HUD construction and Safety standards.

To promote the region's Model Conservation Standards (MCS) BPA is presently employing one approach which emphasizes marketing incentives which have been tempered by sensitivities to the historical housing responsibilities of the states and local governments as well as the dfversity of the many groups conprising the region's building community.

Only recently has BPA begun to realize the extent to which the aanufactured housing industry impacts their utility service terrltories. However, the preemptive nature of HUD manufactured housing regulations, the radical differences between manufactured and site-built housing design, inspection and construction, and the unlque relationships between dealers, manufacturers, and consumers require that BPA develop an approach that is conscious of these differences and respects these constraints.

To ascertain whether manufactured housing can be designed and constructed legally and technically to achleve the conservation levels of the MCS without compromising habitabililty levels, BPA is funding the design and production of five units for research and analysis. In addition, to supplement this effort a number of smaller studies, such as this one, are being structured to have a closer look at some of the key groups which play a role influencing manufactured housing designs. The objective is to gain a greater understanding of the different roles and responslbilities assumed by the varied participants within the manufactured housing process. BPA will then be In a better position to plan a conservation program which complements standard industry practices instead of causing inadvertent disruptions. 
At the time this report was indtiated, the design approval process was the area of manufactured housing regulation with which BPA was the least familiar. The discussion below, therefore, addresses only the Design Approval Primary Inspection Agency (DAPIA) and the design approval requirements contained in the HUD regulations. It provides some insights and discussion describing the organizations currently providing these services to manufacturing plants located in the Pacific Northwest. 
,

. 


\subsection{GENERAL FINDINGS}

All design approvala for new units produced by manufactured housing facilities located In Oregon, Idaho, Montana and Washington are performed by flve DAPIA's. Of these, two are located in southern California, one in Chicago, Illinois, one in Clearwater, Florida and one in Richardson, Texas.

Typical fees for services range from $\$ 100$ to $\$ 250$ to approve a modification to an existing design and $\$ 700$ to $\$ 1200$ to approve a totally new deslgn.

Manufacturers are free to choose the DAPIA or DAPIAs they wish to employ. Thts decision is usually made by evaluating the ranges and quality of services which an individual DAPIA offers to perform.

Each DAPIA is authorized to assure that designs do not violate any of the HUD provisions, but interpretive differences occasionally occur between DAPIAs. If discovered at ali, these interpretive dlfferences are generally found by NCSBCS during their annual spot check of DAPIA design approvals.

Interpretation conflicts are typically caused by the many ambiguities present in HUD's calculational procedures and the way the individual systems and components are reviewed and evaluated for compliance. Evaluation criteria necessary to determine compliance for the totality of the design are not covered in the HUD regulations. Consequently, certain innovative design measures become subject to interpretation. Uniformity problems can only be identified through the NCSBCS spot check or if a nanufacturer makes a request for a formal HUD interpretive decision after which HuD disseninates the findings to other DAPIAs.

The DAPIA representatives from whom this information was gatherered did not feel that the HUD Construction and Safety Standards presented impediments to achieving MCS conservation levels. Rather, they shared the view that the culprits will be lack of consumer enthustasm and the additional cost factors stemming from plant disruptions caused by the occasional super-energy-efficient unit.

Responses from the five DAPIAs indicated that the role they might play in assisting the region's manufacturers achieve MCS levels of conservation ranged from none to significant. If called upon by BPA to assure that a MCS design is in compliance with the HUD standards their present HUD responsibili- 
t1es permit such analysis. But, they are not as willing to assume a role of certifying compliance with the mCs whout first approving and then becoming fanillar with the criteria that they would have to apply.

All the DAPIAs seemed sincere in their wllingness to assist if needed and grateful for being kept informed on what is happening within their client's business environment. In addition, those DAPIAs with greater testing capabilities and resources can provide expert technical services to assist BPA in developing approprlate criteria, general program overviews, evaluations and even some program designs. 


\subsection{THE STUDY}

Th1s study was comprised of six tasks addressed in Sections 3.1 through 3.6. Each was intended to identify specific areas of interest regarding the DAPIAs and their role in the manufactured housing process. In addition, Section 3.7 , which provides several recommendations, was added.

\subsection{DAPIAS THAT PROVIDE SERVICES TO THE NORTHWEST REGION}

The following is a list of the DAPIAs and the manufacturers they service with operations in the Pacific Northwest.

DAPIA and MANUFACTURERS

CONTACT

RADCO

Mike Zieman, (213) 532-3842

16415 Avalon Blvd

Gardena, CA 90247

* Commodore

* Fleetwood

- Fuqua

* Glen River

- Golden West

- Kaufman and Broad

- Marlette

* Moduline

- Rainter

- Rex (D1v. of Cormodore) 
State of California

Mark Steel, (714) 558-4161

Dept. of Housing and

Comaunity Development,

Div. of Codes and Standards

28 Civic Center Plaza

Santa Ana, CA 92701

- Silvercrest

Underwriters Laboratories

John Pabian, (312) 272-8800

333 Pf ingsten Road

Northbrook, IL 60062

* Freedom (Skyline Corp.)

* Homette

- Liberty

Product Fabrication Service

Jim Hopland, (214) 349-9066

2010 Auburn Drive

Richardson, TX 75080

- Redman

Hillborn, Werner \& Carter

B111 Kalker, (813) 584-8151

1627 Myrtle Ave.

Clearwater, Florida

* Guerdon

The basic services performed by each of the DAPIAS include all aspects of design review and evaluation necessary to assure that the resulting designs are in compllance with the HUD Manufactured Housing Construction and Safety standards. In addition, to becone a manufacturer, each plant is required to have on premises a quality assurance manual outlining the controls that the plant wlll empioy to assure a minimun level of quality for its final products. The manufacturers are required to have each model home design and the quality assurance manual that it 1ntends to follow approved by a DAPIA. 
Typically, to approve designs DAPIAs are responsible for reviewing the following:

1. Construction drawings and speciflcations which show the layout of frames, floors, walls, roofs, and chassis; material specifications, framing details, door locations, etc., for each floor plan proposed to be manufactured.

2. Structural analysis and calculation, test data and/or other accepted engineering practices used by the manufacturer to validate the design.

3. Complete heat loss calculations for each significant variation of home design.

4. Floor plans showing room arrangements and sizes, window sizes, emergency exits and focations, locations of smoke detectors, fixed appliance range hoods, and other standard related aspects of the manufactured home that can be shown on the floor plan.

5. Diagrans of the fuel supply systen, potable water system and drain, and waste and vent systems.

6. Wiring dlagrams, including circuit allocation of electrical load and branch circuit locations, a table of the branch circuit protection provided, the type of wiring used and the wiring methods.

7. Details showing the design of air supply and return systens.

8. Details of chassis construction, components, connections and running gear including rating capacities of tires.

9. A list of fixed and portable appliances furnished with the manufactured home including type of appliance, rating of appllance and minimum and maximum performance ratings and/or energy requirements.

10. Installation instructions including spectfications and procedures for the erection and hook-up of the home at its permanent location.

Before HUD issues a Letter of Approval which confers DAPIA status on an organization they must demonstrate to HUD that they have the ability and the personnel to perform these services. They must initially submit for HUD's review organizational outlines, descriptions of testing facilities, samples of design packages with analysis and proposed certifications, and personnel resumes. 
Regardless of their technical qualifications, the basis upon which different DAPIAs conpete their services to win manufacturlng accounts centers on the convenience, quality, efficiency and cost of performing these services.

Because of HUD's and NCSBCS's pervastve regulatory oversight, it was difficult to perceive the services of DAPIAs as being anything less than uniform. And even af ter talking to DAPIAs themselves, it was difficult to conclude that there were indeed ranges of services offered. It was only after talking with manufacturers that the importance of the subtle issues began to appear. The discussion below is intended to be a brief review of these issues for an outsider to the manufactured housing process.

\subsubsection{The Convenience Issue}

The convenience issue generally refers to the location of the DAPIA relative to the corporate offices of the manufacturer and degree of comfort with which the technical staff of each organization works together.

It was interesting that none of the DAPIAs are located In the Pacific Northwest where manufacturing plants have been in high production mode for severai years. However, a closer look at DAPIAs, manufacturers and their locations revealed that in all but one case (HWC, in Clearwater, Florida), the DAPIAs are situated very close to the corporate office of the region's manufacturing facllity. This seems to serve many nanufacturing companies well for a number of reasons. Foremost is that the highest trained engineering staff within the corporation usually develops the designs for new models and they are typically located at the corporate headquarters with the marketing executives. Second, many corporations have more than one plant and use the same designs in each. If each plant were to submit the designs for the models they produce directly to their own DAPIAs, companies would be paying duplicate fees for multiple approvals of the same design.

\subsubsection{The Quality Issue}

From the manufacturer's point of view, the quality of the work performed by the DAPIA is based on a DAPIA's reputation regarding approvals for model designs which have been found at some later date to have vlolated the HUD code. Such mistakes can cause the manufacturer expensive recalls, repairs or 
replacements. On the other hand, manufacturers want DAPIAs to be flexible, up-to-date on new technologies and innovative designs and serve as an advocate on their behalf with respect to HUD.

Every year HUD, through an agent, performs spot plan checks on the designs approved by each DAPIA. (Every three years HUD negotiates a contract with an organization to perform these responsibilities on their behalf. At the present time, NCSBCS is the agent.) The DAPIA then receives a rating from HUD which is based on such things as their ability to apply and interpret the HUD code, their abllity to approve the use of new technologies in a way that does not violate any code provisions, their testing procedures, etc.

The ratings categories are expressed in terms of "Adequate," "Needs Improvement" and "Not Adequate." Once NCSBCS does the check and recommends a rating to HUD, a hearings and appeals process which takes ciose to a year may occur if HUD decides to institute a disqualification procedure against a DAPIA. DAPIAs are not aware of the NCSBCS recommended ratings until HUD notifies them directly, and it frequently takes 6 to 9 months for HUD to get back to a DAPIA after NCSBCS does their spot check. Manufacturers are affected when spot checks reveal that certain designs are not in compliance with the HUD standards. They may be required to resubmit and have their designs corrected for future use or they may be required to make costly structural changes to units already sold.

\subsubsection{Efficiency Issues}

The issues regarding the efficiency of a DAPIA usually refer to the turnaround time needed to review plans, perform analysis, conduct tests and forward the approvals. The DAPIAs typically take three days to approve a design modification to an existing model and as long as up to three weeks to complete a new design review. One DAPIA (RADCO), offers the capability of same day deslgn approvals with the use of computer telecommunications. Obviously, one of the factors affecting the time that it takes to review designs has to do with the complexity and the extent of the design review request. Another factor is whether the DAPIA has certain testing facilities at his location or whether he must nust obtain these services elsewhere. 
Also discussed as an issue of efficlency is recordkeeping. Every manufacturer nust keep a copy of each DAPIA-approved design for models produced on the plant site. However, there are also recordkeeping requirements placed on DAPIAs. In addition to sending copies of all designs to NCSBCS, they nust keep a copy of every design they review, every test they conduct and all their analysis. Most admlt that it is virtually impossible to do any more than warehouse them and none. including NCSBCS, have ever attempted to categorize them in anyway except by manufacturer, for any adninistrative, technical or research purpose.

\subsubsection{Cost_Issues}

Certainly the costs of providing services is an Influencing factor. The charges for DAPIA services fall into two groups; either they were based on standard professionai fees for engineering time or they were flat fees. Either way, there does not seen to be a big difference in price. The end result is that DAPIAs charge about $\$ 200$ (depending on what is actually being modified) to approve a modification to an existing model. The price to approve a new model design is generally about $\$ 1000$. If the new design is so novel as to require many additional tests such as tests for materiai endurance or fire spread, the costs could be greater.

The other cost consideration that may piay a role in selecting a DAPIA has to do with the other related consulting type services offered by DAPIAs to the manufactured housing industry and unspoken benefits and professional courtesies extended to full clients.

\subsection{THE PROCESS USED BY MANUFACTURERS TO OBTAIN DAPIA APPROVAL FOR NEW DESIGNS AND DESIGN CHANGES}

The process used to obtain approvais is a relatively simple one and one prescribed by HUD regulations. A manufacturer designs a manufactured housing unit or has one designed for him by some outside design consultant. He then sends to the DAPIA the drawings as well as any other information, documentation or testing results which may be required to receive the certification.

Accompanying specifications, testing results and other documentation are frequently required because even new models use standardized component specifications which are already in use within the industry. Not everything 
in a new nodel is really new to the industry. The DAPIA then checks to see that everything is already properly certified. In addition, he approves and certifles any aspects of the new design included in the package which are not already certified. At that point, he is actually certifying that the whole design, with all its accompanying precertified approvals, will produce a unit in compliance with the HUD Standards.

If there is a design problem, the DAPIA usually will first informally notify the manufacturer to try and resolve it. If the problem cannot be resolved to the satisfaction of both parties, the DAPIA returns the drawings wthout a stamped certification of approval. If the drawings comply with all the HUD standards, the certifying stamp is placed on the drawings and the drawings are filed with NCSBCS, the DAPIA and the manufacturer. No models are produced until designs are approved.

It should be noted here that each of the DAPIAs serving the Pacific Northwest (except for the state of Callfornia) is in the consulting business and performs design analysis, engineering analysis, materials testing, research and other technological assessments for the building industry in addition to providing services as a DAPIA. Consequently, when a manufacturer has a technical question or requirement, it is common practice to use the expertise, testing laboratory facilities and technical skills of organizations such as the Underwriters Laboratorles, or RADCO, from whon they are already acquiring DAPIA services.

The HUD regulations specifically prohibit DAPIAs from designing those units they must also approve. But, a manufacturer is free to go to any professional design group, including any DAPIA, for this service, providing it is not the one making the certification of complance. Unfortunately, this is one of those situations where the rule is easier to state than to apply. The definltion of what constitutes "to design" is open to interpretation. Does "design work" mean Just sitting down and doing the drawing, or does it include the calculational and engineer Ing analysis which must accompany a plan? such problems are not new to the industry or HUD. 


\subsection{THE COST OE SERVICES RENDERED BY A DAPIA AND THE UNIFORMITY OF THESE CHARGES}

As mentioned above, the charges for services are not identical in the way they are adminlatered. However, the end result is that all the DAPIAs are generally competitive with each other for the1r DAPIA services. As mentioned above, the cost for a new nodel to be approved is generally from $\$ 700$ for a single wide to about $\$ 1200$ for a double wide and the cost for a typical design modification is between $\$ 100$ and $\$ 300$ respectively. No DAPIA could provide precise estlmates wlthout an actual design to reference. The anounts for particular slngle wide units, and double wide untts differ. The nature of the analysis and the extent to which materials or other structural testing would be necessary also significantly impact the cost.

\subsection{THE AMOUNT OF TIME NEEDED TO CERTIFY A NEW DESIGN}

As noted above, it can take from several hours to several weeks for a manufacturer to obtain a design approval. Typlcally, 3 days to 1 week is what manufacturers expect. However there are circumstances where 1n order to accomnodate an imnediate need, a DAPIA will expedite a review and transmit both the designs and the notification of approval by either a telefascimile or computercommunication.

The State of California DAPIA seems at present to have the slowest turnaround $t$ Ime. As an element of state government, it does not have independent authority to remedy its manpower needs simply by hiring qualfied staff as needed or adjusting Its fee structure to cover 1 ts costs. Like other state regulatory agencies, the DAPIA office is subject to hiring freezes and other policies which llmit any consideration of maintaining or expanding services. They report that it takes almost two and sometimes three weeks to return an approved design back to a manufacturer.

\subsection{THE APPEALS PROCESS}

The HUD regulation (24 CFR Ch.20, Section 3282.206) provides an appeals process for manufacturers when there is a disagreement with the DAPIA. 
The manuacturer may write to the Secretary of HUD to request a hearing or presentation of views. The HUD regulations specifically prohibit a nanufacturer from beginning to manufacture or produce a unit or design which is not yet approved. Only after the design or design change is approved, can the manufacturer begin to produce the unit. The experience of most DAPIAs is that it takes about two months for HUD to respond and provide the forum for expressing views.

More commonly, the DAPIA and the manufacturer are not in disagreement with each other but rather they agree that a certain provision of the HUD standard is inappropriate or no longer applicable. When this occurs, the DAPIA will write a No-Action Letter to HUD on the manufacturer's behalf to request that HUD not take any action against the manufacturer for violating a provision of the standards.

An example of this is the HUD requirement that a utility inlet for a foundation be placed on the left slde of the unit but because of some conditions at the intended site, the manufacturer wants to place it on the right. If HUD agrees, HUD prepares and returns an Alternate Construction Letter to the DAPIA and the manufacturer. Typlcally, it takes 4 to 6 weeks for HUD to respond to a No-Action letter.

This example illustrates that, because more units are custon designed today than ever before, manufacturers of ten must know details about the intended location and site in order to satisfy their customers. It is possible this knowledge might be benificial in the application of certain energy conservation options such as proper window orientation.

\subsection{THE DAPIA ROLE IN THE DESIGN, ANALYSIS AND APPROVAL OF MODEL CONSER- VATION STANDARD HOMES}

Each of the DAPIAs was interested in Bonneville's efforts to have manufactured housing units designed to the MCS and each voiced appreciation at having been Informed as to what outside influences their clients might be trying to respond to in the coming year.

However, the role they thought they could assume logically if BPA were to decide to implement an aggressive marketing program ls still somewhat vague. They were not prepared to discuss what role they would like to play. 
However, they were amenable to hearing exactly what BPA was planning to do and then perhaps would offer some advice or begin to discuss a role. The reason for their ambivalence is, principally, that as a DAPIA they are fully aware of the llabilities which can be assumed by being a key certifying agency .

In fact throughout the conversations, DAPIA representatives emphasized that the ultimate responsibility of complying with the HUD standards resides with the manufacturers. Certifications as we call them throughout this paper and as they are referred to within the industry are in fact "approvals" surrounded with bollerplate language intended to absolve the DAPIA from mistakes and reaffirm that the HUD Standards must still be met by manufacturers.

If asked to certify or "approve" that BPA designs comply with HUD Standards, there wlll be little question of DAPIAs' cooperation as they are already authorized to do this. However, it is unlikely that DAPIAs will assume the responsibility of certifying designs to be in compliance with the MCS unless BPA is prepared to develop clear, unambiguous, non-controversial criteria which they can use.

Most DAPIAs also offered to assist in formulating any criteria that BPA might want to use depending on how much time it was likely to take and the nature of the resources that might be available. In addition many offered to approach their manufacturing clients on BPA's behalf to of fer technical reassurance if desired.

As a group, the DAPIAs strongly felt that insufficient customer support is the only impediment to achieving the MCS conservation levels in manufactured housing. Many DAPIAs have already seen the industry produce very efficient units with passive and active solar features, and other innovative energy conserving features. Some of these DAPIAs participated in conservation design programs with the Solar Energy Research Institute (SERI) and the U.S. Department of Energy (DOE). In addition, they all felt that new technologies could be accommodated easily regardless of the HUD regulations. They cited, as an exanple, air to air heat exchangers which were not required to be reviewed by DAPIAs unt 11 Pebruary of 1985 . The regulations permit the inclusion of any new technologies into a design as long as they 
are not found to conflict with regulatory provisions. They concluded, therefore, that the HUD standards have not been the reason for the industry's sluggish attitude toward energy improvenent.

Surprisingly, no one argued that energy conserving units could not be designed and built and that the extra costs of the energy features would be an overriding obstacle to the design and sale of super-conserving units. Rather, the disruption of the production processes employed at the individual plants to build a limited number of energy conserving homes was likely to be at the core of institutional resistance. Thelr opinlon almost uniformly is that super-conserving units are not easily accommodated by the assembly line process, which provides the fundamental cost advantage to the manufactured housing industry. Without a clientelle that is going to demand these units in volume, the costs to produce custon units will increase the price of plant operations dramatically. The BPA demonstration program currently being performed by Battelle Northwest should provide nore insight into this issue.

In their own ways, each DAPIA also expressed concern for the overall safety and habitability of the manufactured housing units that meet the MCS. The HUD standards are construction safety standards and in the format of component performance standards. Consequently, the effects of certain design measures on the totality of the unit are sometimes outside the scope of anyone's authority and are only evaluated as a part of independent research projects. Many issues such as fire spread, venting roof cavity requirements, and the required amount of air changes affecting the life safety and habitability of the total unit are examples of issues not addressed in the HUD Standards.

\section{7 RECOMMENDED ACTION}

Based on the above discussion, BPA should pursue the following activities that will increase understanding of manufactured housing and help design programs to promote production of energy conserving manufactured homes:

- BPA should undertake several continuing studies to learn more about the manufactured housing consuners, industry participants, design trends and construction processes wich will be affecting the units purchased in the Pacific Northwest in the next few years. Such studies 
should also include a closer look at how manufactured housing units are typically financed and how financing alternatives affect the ultinate consumer decision to purchase energy conserving designs. BPA should develop clear criteria which DAPIAs can use to make a determination that a design is In compliance with the MCS. Alternate methods for developing these criteria should be considered, including the review of heat loss calculations typically performed by DAPIAs to see whether they can be used to ascertain compliance with MCS. Any criteria developed should consider the costs of design and design review since it may be appropriate for BPA to reimburse manufacturers for these costs.

- BPA should institute a training progran to familiarize the DAPIAs, dealers, manufacturers and IPIAs with the MCS, the criteria to be developed and BPA's objectives in the region.

- BPA should consider whether it is necessary or politically desirable to gain HUD's concurrence to ask DAPIAs to verify compliance with the MCS.

- As a courtesy to the DAPIA's who have been very cooperative and generous in giving thought and time to this study and to maintain a liason with them, BPA should keep them apprised of the region's manufactured housing research program on a regular basis. 


\section{DISTRIBUTION}

No. of

Coples

20 Steve Onisko

Bonneville Power Adwinistration

P.O. Box 3621

Portland, OR 97208

5 Jean Boulin

U.S. Department of Energy

Porrestal Building, GH--68

1000 Independence Avenue, S.W.

washington, D.C.

David Conover

NCSBCS

481 Carlisle Drive

Herndon, VA 22070

Frank walter

Manuf actured Housing Institute

1745 Jefferson Davis Highway

Arlington, VA 22202

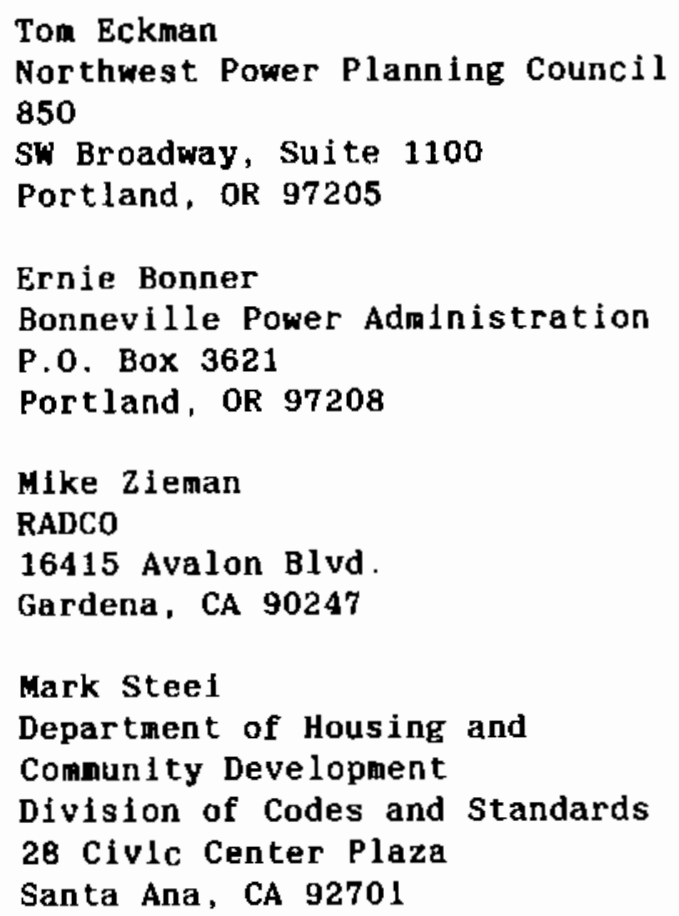

No. of

Copies

John Pabian

Underwriters Laboratories 333 Pfingsten Road

Northbrook, IL 60062

$J i$ in Hopland

Product Fabrication Service 2010 Auburn Drive Richardson, TX 75080

Bill Kalker Hillborn, Werner \& Carter 1627 Myrtle Avenue Clearwater, FL

30 DOE Technical Information Center

ONSITE

DOE RIchland Operations office

D.R. Senga

21 Pacific Northwest Lab

S. Balistocky (5)

A.D. Lee (5)

S. Smith

B. L. Mohler

R.C. Adams

T. Secrest

Publishing Coordination (2)

Technical Information (5) 
